\title{
Legacy patterns in the abundance of epigaeic mountain beetles after the eruption of the Puyehue-Cordon Caulle volcanic complex (NW Patagonia, Argentina)
}

\author{
Adriana Ruggiero $₫$ \& Victoria Werenkraut \\ Laboratorio Ecotono - Universidad Nacional del Comahue (INIBIOMA-CONICET). Bariloche, Argentina
}

\begin{abstract}
AвSTRACT. Organisms that survive a volcanic eruption are part of the biological legacies that are fundamental to subsequent succession and ecosystem development. In January 2012, the summer immediately after the eruption of the Puyehue-Cordón Caulle volcanic complex, we evaluated the short-term response of epigaeic beetle abundance to ash deposition. We focused on three mountains (La Mona, Bayo, Challhuaco) in northwestern Patagonia (Argentina) that were differentially affected by ash deposition. We re-established 32, $100 \mathrm{~m}^{2}$ sampling plots of nine pitfall traps, every $100 \mathrm{~m}$ of altitude from the base to the summit of each peak, which we had previously sampled in January 2005 and 2006. We compared the shape of pre- and post- eruptive abundance-elevation relationship (AER), and assessed whether the relative importance of environmental predictors of AER (ambient energy, vegetation cover, plant species richness and soil attributes) changed after the eruption. La Mona and Bayo were most affected by ash deposition; Challhuaco was considerable less affected. Yearly fluctuations in abundance levels were significant in Bayo; here, the shape of AER changed significantly after the eruption. In La Mona, abundance was similar among sampled years, and the shape of AER departed weakly from the overall trend after the eruption. In Challhuaco, abundance tended to increase weakly with time, and the shape of AER did not change after the eruption. Gravel percentage and tree canopy cover were the two most important predictors of pre-eruptive AER, but only tree canopy cover remained as important after the eruption. We conclude that short-term effects of ash deposition on epigaeic mountain beetles were subtle and suggest that the presence of a gradient of ash deposition may lead to associated patterns in biological legacies. Long-term monitoring is essential to fully understand the structural and functional recovery of these mountain ecosystems.
\end{abstract}

[Keywords: Ash deposit, Coleoptera, elevation gradient, generalized additive models, multi-model inference approach]

\begin{abstract}
Resumen: Patrones de legado en la abundancia de coleópteros montanos epigeos luego de la erupción del complejo volcánico Puyehue-Cordón Caulle (NW Patagonia, Argentina): Los organismos que sobreviven a una erupción volcánica son parte fundamental del legado biológico determinante de la subsecuente sucesión y desarrollo del ecosistema. En enero 2012, en el verano inmediato a la erupción del complejo volcánico PuyehueCordón Caulle, evaluamos la respuesta a corto plazo de la abundancia de coleópteros epigeos al depósito de ceniza. Estudiamos tres montañas (La Mona, Bayo, Challhuaco) en el noroeste de la Patagonia (Argentina), afectadas diferencialmente por el depósito de ceniza. Re-establecimos 32 sitios de muestreo con nueve trampas de caída distribuidas en $100 \mathrm{~m}^{2}$, ubicados cada $100 \mathrm{~m}$ de altitud desde la base a la cima de cada montaña, y muestreados previamente (enero 2005, 2006). Comparamos la forma pre- y post- eruptiva de la relación abundancia-elevación (AER). Determinamos la importancia relativa de predictores ambientales de AER (energía ambiental, cobertura de la vegetación, riqueza de especies de plantas, y atributos de suelo) pre- y post- erupción. La Mona y Bayo fueron más afectados por el depósito de ceniza; Challhuaco fue menos afectado. Los niveles de abundancia fluctuaron significativamente en Bayo, se mantuvieron constantes en La Mona y aumentaron levemente en Challhuaco. Luego de la erupción, la forma de AER cambió significativamente en Bayo, se apartó débilmente de la tendencia promedio en La Mona, y no cambió en Challhuaco. El porcentaje de gravas y la cobertura del dosel arbóreo fueron los predictores más importantes de AER pre-eruptivo; solamente la cobertura del dosel arbóreo permaneció como importante luego de la erupción. Los efectos a corto plazo del depósito de ceniza sobre la abundancia de coleópteros epigeos fueron sutiles y sugieren que la presencia de un gradiente en el depósito de ceniza puede conducir a patrones asociados en los legados biológicos. Un monitoreo a largo plazo será indispensable para comprender la recuperación estructural y funcional de estos ecosistemas montanos.
\end{abstract}

[Palabras clave: depósito de ceniza, Coleoptera, gradiente de elevación, modelos aditivos generalizados, enfoque de inferencia por modelos múltiples]

\section{INTRODUCTION}

Volcanic activity is a powerful driver of environmental change at multiple geographical and temporal scales (Simkin
1993). Although, from a human-lifetime perspective, volcanic eruptions may appear as rather infrequent events they actually are not so rare at global or regional scale (Simkin 1993), and whenever they occur they can

\section{Editor invitado: Thomas Kitzberger}


modify entire landscapes through a diversity of geophysical disturbances, including the precipitation of volcanic ash or tephra that may blanket extensive areas (e.g., Mount St Helens, >100000 ha: Dale et al. 2005; PuyehueCordón Caulle, > 23 million hectares: Gaitán et al. 2011). The precipitation of volcanic ash is susceptible to be translated into an ecological response (Turner et al. 1997; Dale et al. 2005; Kitzberger 2013). However, the ecological response may vary considerably among different environments, and the natural capacity of organisms to tolerate (or not) ash deposition (Dale et al. 2005).

Organisms that survive a volcanic catastrophe (e.g., animals, plants, fungal, microbial) have been increasingly recognized as biological legacies that are fundamental to the ecological response, as they can have significant influences on the path and rates of subsequent succession and ecosystem redevelopment (Franklin 1990; Franklin et al. 2000; Dale et al. 2005). It has been suggested that the level of biological legacies (i.e., the number and kind of surviving organisms and levels of organic debris) is the most important variable influencing ecosystem recovery (Franklin 1990), and several examples suggest they indeed played a significant role in the restoration of plant and animal communities after severe volcanic eruptions (e.g., Mount St. Helens: Dale et al. 2005; Kasatochi Island: Talbot et al. 2010). The presence of a continuum of disturbance intensities may lead to similar gradients in biological legacies (Franklin 1990).

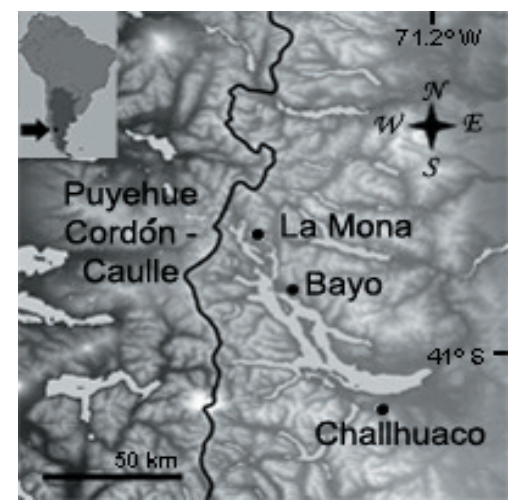

Figure 1. Map of the study area showing the location of Bayo $\left(40^{\circ} 45^{\prime} \mathrm{S}, 71^{\circ} 36^{\prime} \mathrm{W}\right)$, La Mona (40 $\left.34^{\prime} \mathrm{S}, 71^{\circ} 42^{\prime} \mathrm{W}\right)$, Challhuaco $\left(41^{\circ} 13^{\prime} S, 71^{\circ} 19^{\prime} \mathrm{W}\right)$, and the Puyehue-Cordón Caulle Complex (40 $\left.32^{\prime} \mathrm{S}, 72^{\circ} 7^{\prime} \mathrm{W}\right)$.

Figura 1. Mapa del área de estudio mostrando la ubicación de las montañas: Bayo $\left(40^{\circ} 45^{\prime} \mathrm{S}, 71^{\circ} 36^{\prime} \mathrm{W}\right)$, La Mona ( $40^{\circ} 34^{\prime}$ $\left.\mathrm{S}, 71^{\circ} 42^{\prime} \mathrm{W}\right)$, Challhuaco $\left(41^{\circ} 13^{\prime} \mathrm{S}, 71^{\circ} 19^{\prime} \mathrm{W}\right)$ y el complejo volcánico Puyehue-Cordón Caulle (40 $32^{\prime}$ S, $72^{\circ} 7^{\prime}$ W).
However, legacy patterns may be not so easy to quantify because of the relative unpredictable nature of volcanic activity coupled with the rather infrequent availability of data from pre-disturbance communities.

The goal of the present study was to quantify legacy patterns in the abundance of epigaeic mountain beetles using three mountains differentially affected by the eruption of the Puyehue-Cordón Caulle volcanic complex, and where detailed analyses of preeruptive abundance patterns were available (Werenkraut 2010; Werenkraut \& Ruggiero 2014). We compared the post-and pre-eruptive abundance-elevation relationship (AER) along a gradient of ash deposition. Ash deposition is known to produce lethal effects on many insect species and to significantly decline arthropod populations (Wille \& Fuentes 1975; Marske et al. 2007; Buteler et al. 2011). In pre-eruptive conditions, AER predominantly followed a hump-shaped pattern within our study area. Also, the abundance of epigaeic beetles increased with tree canopy cover and herb cover, and decreased with the increase in litter accumulation and proportion of gravel (Werenkraut 2010; Werenkraut \& Ruggiero 2014). We evaluated whether 1) the shape of AER in the summer immediately after the eruption differed from pre-eruptive reports, and 2) the relative importance of different environmental predictors of abundance variation (temperature at ground level, vegetation and soil attributes) was modified after the eruption. The short-term response of epigaeic beetles to ash fall may result in legacy patterns that can be considered as useful baseline for future long-term monitoring of ecosystem development and recovery.

\section{METHODS}

\section{Study Area}

The study was conducted in north-western Patagonia $\left(41.08^{\circ} \mathrm{S}, 71.02^{\circ} \mathrm{W}\right.$, Figure 1$)$ within the Nahuel Huapi National Park (Argentina). The region is characterized by an average temperature $<18{ }^{\circ} \mathrm{C}$ during the summer season, and during winter, it is $<4{ }^{\circ} \mathrm{C}$ (Rudloff 1981). More than $70 \%$ of the annual precipitation is concentrated during fall and winter (Jobbágy et al. 1995); mean annual precipitation strongly decreases along a west-east gradient from more than $3000 \mathrm{~mm}$ to $\sim 300 \mathrm{~mm}$ (Barros et al. 1983). Subantarctic forests dominate the landscapes towards the west, and the Patagonian steppes are found towards the east (Paruelo et al. 1998). A similar ecological and 
biogeographical transition occurs with altitude and, at about 1600 m.a.s.l., it is the transition from the Subantarctic forests and shrublands of semi-arid scrub vegetation that grow downslope to the highaltitude Andean steppes composed of xerophytic shrubs and herbs that often present adaptations to cold and windy conditions (Ferreyra et al. 1998).

The study area is within the Southern Volcanic Zone, a region of high current volcanic activity that begins just south of the Aconcagua massif and extends along the Andes for $1400 \mathrm{~km}$ up to Hudson volcano in southern Chile (Clapperton 1993). In northern Patagonia, the Nahuel Huapi area has been affected by several explosive pulses of the Puyehue-Cordón Caulle volcanic complex during the last 10000 years (Villarosa et al. 2006). The last eruption, started on June $4^{\text {th }} 2011$, which sent out 950 million tons of ash, sand and pumice stone that covered more than 23 million of hectares over the Neuquén and Río Negro Provinces in Argentina (Gaitán et al. 2011; daily reports available at http: //www.sernageomin.cl.

We selected three mountains situated at different locations along the west-east transition (Figure 1) that were differentially affected by ash deposition: 1) La Mona $\left(40.34^{\circ} \mathrm{S}, 71.42^{\circ} \mathrm{W}\right.$, annual precipitation: $1950 \mathrm{pmm}$ ) and 2) Bayo (40.45 $\mathrm{S}, 71.36^{\circ} \mathrm{W}, 1650$ $\mathrm{pmm}$ ) are about $40-50 \mathrm{~km}$ apart from the eruption, and 3) Challhuaco is about $120 \mathrm{~km}$ apart $\left(41.13^{\circ} \mathrm{S}\right.$, $71.19^{\circ} \mathrm{W}, 1100 \mathrm{pmm}$ ); according to Gaitan et al. (2011) ash deposition in La Mona and Bayo respectively reached 7.5-10 and 10-15 cm, whereas in Challhuaco total ash deposition was less than $2 \mathrm{~cm}$.

\section{Beetle sampling}

A suitable field comparative design to infer a causal effect of ash fall on the abundance of beetles would require to fully control for both the temporal change (before-after) in the studied system and spatial impact (control-impact) of the ash fall (Hulbert 1984); actually, sampling multiple impacted and control sites, before and after a disturbance (BACI sampling design), has been recommended as an optimal design for environmental impact assessment (e.g., Underwood 1992). Although we relied on pre-eruptive (January 2005-2006) abundance data for the three mountains studied, we lack pre-eruptive data from a mountain not affected by ash deposition. The impossibility of having before-after data for a control mountain represented a drawback of our study; however, it was minimized by the location of the three studied mountains along a gradient of ash deposition. This feature in the design of our study makes it to approach a before-after gradient (BAG) sampling design that has been considered as a powerful alternative to BACI design for environmental impact assessment (Elis \& Schneider 1997).

We used GPS to find the exact location of the 32 sampling plots that had been previously sampled in 2005-2006 and thus, 9-12 plots were re-established at about $100 \mathrm{~m}$ of altitude away from each other, from the base to the top of each mountain. We collected beetles using 288 plastic pitfall traps (diameter, $9 \mathrm{~cm}$; depth, $12 \mathrm{~cm}$ ), arranged in thirtytwo $100-\mathrm{m}^{2}$ grid plots of nine traps. Traps were filled with diluted propylene glycol (40\%) and a drop of soap. Pitfall traps were operative as soon as established in the field and were opened over 7 days during January 2012. We pooled the contents from the nine pitfalls to one sample for each plot. All samples were preserved in $80 \%$ ethyl alcohol. All the collected material was carried to Ecotono Laboratory, Universidad Nacional del Comahue, Bariloche, Argentina to complete the individuals count.

The abundance of individuals was the total number of individuals caught at each plot; "abundance" should be interpreted with caution here because pitfall trapping allows suitable estimations of relative activity-density rather than absolute abundance (Baars 1979). Nonetheless, our sampling effort (=9 pitfall traps per sampling plot with seven days of activation during each sampling period) approaches Cheli \& Corley's (2010) recommendation of using five traps per experimental unit with ten days of activation, to obtain reliable measures of species richness in the most extreme arid Patagonian steppes. Hence, we are confident that our estimations reflect a reliable picture of the epigaeic beetle community structure and thus they are valid to compare pre- and posteruptive spatial patterns.

\section{Ash deposition}

At each plot, we dug a plastic test-tube $(5 \mathrm{~cm}$ diameter and $35 \mathrm{~cm}$ height) into the ground to carefully remove a core from the soil whereby to measure the height of ash deposition in $\mathrm{cm}$.

\section{Environmental variables}

During January 2012, we measured a total of 19 environmental variables on each sampling plot, that were known to be associated with the spatial variation in abundance at pre-eruptive times, as reported in Werenkraut (2010), and Werenkraut \& Ruggiero (2014). These previous works should be consulted for details of the field measurements and lab protocols. Here, we mention that we measured variables representing 1) ambient energy, 2) vegetation, and 3) soils, as follows:

Ambient energy: we mounted one HOBO H8 logger (Onset Computer Corporation, Bourne, MA, USA) on a pole fixed at the centre of each 10 x $10 \mathrm{~m}$ sampling plot to measure minimum daily temperature (TMIN), and daily temperature range (TVAR) at ground level from data recorded every $2 \mathrm{~h}$ during the week that pitfall traps were active. Differences in sun exposure between slopes at these temperate latitudes were represented by a qualitative variable ( $\mathrm{SUN}=\mathrm{N}>\mathrm{NW}>\mathrm{NE}>\mathrm{W}>\mathrm{E}>\mathrm{SW}>\mathrm{SE}>\mathrm{S}$ ).

Vegetation: we sampled the vegetation in each of the 10x10-m sampling plots and classified all plants 
recorded according to their growth forms: i) herbs, ii) shrubs, and iii) trees, as proposed by Ezcurra \& Brion (2005). We counted the total number of species of herbs (HERBSP), shrubs (SHRUBSP) and trees (TREESP) recorded on each sampling plot to estimate species richness. We made four readings of canopy cover using a spherical densitometer facing each of the four cardinal directions, and averaged the cover values to estimate an overall estimation of tree canopy cover for each plot (TREECOV). The proportion of each sampling plot covered by shrubs (SHRUBCOV) was estimated visually. We estimated the herb cover for each $10 \times 10-\mathrm{m}$ plot by haphazardly throwing four times a $0.50 \times 0.50-\mathrm{m}$ wooden frame subdivided into a 25-celled nylon string grid. In each placement, we estimated the proportion of cells covered by herbs. We averaged these four values to estimate herbaceous cover (HERBCOV). We removed as much litter as was necessary to dig in the pitfall trap to obtain equivalent samples of litter biomass at each plot. Samples were stored in paper bags, oven- dried to constant mass at $60^{\circ} \mathrm{C}$ and weighed to estimate dry litter biomass (LITTER).

Soil characteristics: for each plot-sample, we extracted samples from the top 10-cm of soil at three randomly selected points to determine water $\mathrm{pH}$ (PHH2O; potentiometric determination, Thomas 1996), volcanic $\mathrm{pH}$ (PHVOLC), which is a likely indicator of volcanic influence in soil formation (potentiometric determination, Blakemore et al. 1987 a,b), proportion of silt, sand, and clay (SILT, SAND and CLAY) (Klute 1986), proportion of organic matter (OM) (Pipette Method, Klute 1986) and soil humidity (HUM=[(wet weightdry weight)/wet weight]x100). We haphazardly extracted three additional samples from each plot using a cylinder of known volume $\left(96.21 \mathrm{~cm}^{3}\right)$. These samples were dried at $105^{\circ} \mathrm{C}$ for $24 \mathrm{~h}$ and sieved to $2 \mathrm{~mm}$. From particles less than $2 \mathrm{~mm}$, we determined bulk density (BULDEN)=dry weight/ cylinder volume. Higher values of BULDEN are related to more compacted soils. From samples with larger particles, we estimated the proportion of gravel (GRAVEL=gravel weight/total weight). We averaged BULDEN and GRAVEL estimations over the three samples.

\section{Analyses of data}

The shape of the AER relationship: we used the mgcv package in R (Wood 2001; R Development Core Team 2011) to fit a generalized additive model (GAM) to the AER data to test for significant differences in the mean abundance of beetles caught among years, and to test whether a smoother function of elevation accounted for a significant proportion of the shape of the AER in each site, using the data from the three sampling periods (January 2005, 2006 and 2012).

$$
\begin{aligned}
& \log _{10}(\text { Abundance })=\alpha+f(\text { elevation })+\text { factor }(\text { year })+\varepsilon i \text {, } \\
& \varepsilon i \sim N(0, \sigma 2)
\end{aligned}
$$

where $\log _{10}$ (Abundance A $_{i}$ was the number of individuals (log-transformed) modeled as a smoothing function ( $f$ ) of "elevation" and "year", being a nominal variable with three levels (January 2005, January 2006 and January 2012); we log-transformed abundance data to satisfy the assumptions of a normal distribution $(\mathrm{N})$ of errors ( $\varepsilon i)$ with mean zero $(0)$ and variance $(\sigma 2)$ (Zuur et al. 2009). In a second run, we required the interaction term between "elevation" and "year ${ }_{2012}$ " to test whether the shape of AER changed after the eruption (January 2012).

$\log _{10}\left(\right.$ Abundance $\left._{\mathrm{i}}\right)=\alpha+f($ elevation $)+$ factor $($ year $)+f\left(\right.$ elevation, year $\left._{2012}\right)+\varepsilon i$,

$$
\varepsilon \mathrm{i} \sim \mathrm{N}(0, \sigma 2)
$$

The interaction term in a GAM is different from one in linear regression, and it allows testing the deviation of AER in January $2012\left(\right.$ AER $\left._{2012}\right)$ smoother from an overall smoother fit on all data points (= overall elevation effects on all years). If $\mathrm{AER}_{2012}$ is significant it means that the shape of the AER changed after the eruption. The command gam.check in the mcgv package was used to assess normality, homogeneity and model fit, using logtransformed abundance data (Zuur et al. 2009).

The association of abundance with environmental factors: we used a multi-model selection approach of inference and the modelaveraging procedure implemented in the glmulti package (Calcagno \& Mazancourt 2010) to estimate the relative importance of each predictor variable to account for mean abundance variation by using the Akaike weight (wi), which measures the relative likelihood of a model to be the best given a dataset; the importance of a given variable arose from the sum of the $\mathrm{w}_{\mathrm{i}}$ of all the models in which the variable participated (Burnham \& Anderson 2002). We classified the environmental variables into groups to represent ambient energy, vegetation cover, plant species richness, physical composition of soils, and chemical properties and organic matter of soils. We first generated multiple models that included all possible combinations of the given " $\mathrm{m}$ " explanatory variables in each environmental group. Then, we generated a composite model that combined the most single important variable in each environmental group, and compare their relative importance to account for abundance variation between pre- and post- eruptive conditions. For January 2012, the composite model also included the effect of ash.

\section{RESULTS}

\section{Ash deposition and AER patterns}

We confirmed that La Mona and Bayo were the two altitudinal gradients most affected by the ash deposition (Figure 2); the highest level of ash deposition (>10 cm between 900-1600 


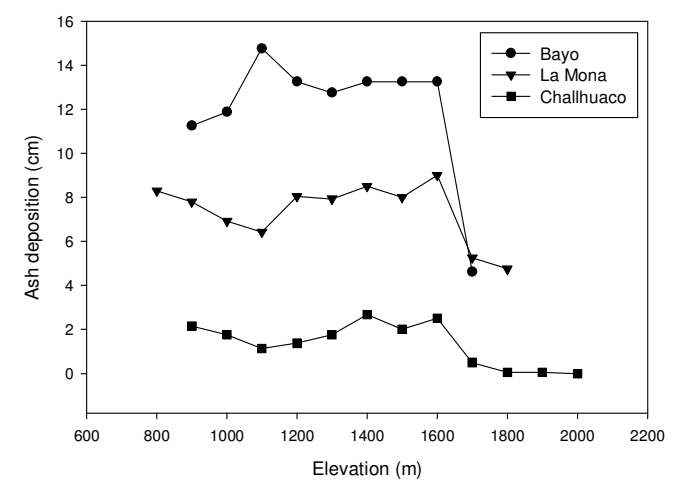

Figure 2. Elevational variation in ash deposition across the three mountains studied.

Figura 2. Variación altitudinal en el depósito de ceniza en las tres montañas estudiadas.

m.a.s.l.) was found in Bayo, followed by La Mona with $\sim 8 \mathrm{~cm}$ between $800-1600$ m.a.s.l., and considerably lower levels of ash deposition $(\leq 2 \mathrm{~cm}$ ) were recorded in Challhuaco (Figure 2). Thus, our measurements of ash deposition at local scale, on 32 field sampling plots, were in agreement with those of Gaitán et al (2011).

We collected a total of 6483 individuals of beetles in January 2012, which exceeded the total number of individuals collected in January 2005 (4569 individuals) and 2006 (4285 individuals). The GAM applied to the AER data adequately described the elevational variation in abundance (Table 1a, Figure 3). This analysis revealed yearly fluctuations in the level of abundance, mostly in Bayo (Table 1a, Figure 3). Here, there was a significant effect of time (year) on the mean number of individuals caught (Table 1a); actually, the mean number of individuals caught per plot (n) decreased from $n=180$ in 2005 to $n=30.4$ in 2006, and then, in January 2012, it increased to a similar level to those recorded in $2005(n=180.4)$. In La Mona, the mean abundance of individuals caught did not differ significantly across years, and in Challhuaco there was a tendency for the abundance of individuals caught to increase with time, although the overall effect of time was marginally significant (Table 1a).

The shape of the AER was accounted significantly by the smoother function fit to the abundance data (Table 1a). In January 2012, the shape of the AER in Bayo departed significantly from the overall trend; in La Mona there was a weaker tendency for the shape of AER to be different from the overall trend $(P=0.09)$, and the shape of AER in Challhuaco did not change after the eruption (Table 1b, Figure 3).
Table 1. GAMs model fit to AER data to: a) test for differences in the levels of $\log _{10}$ (abundance) and shape of the AER on three altitudinal gradients (Bayo, La Mona and Challhuaco) (model without interaction). The parametric coefficients represent differences in units of $\log _{10}$ (abundance) observed in January $2006\left(\mathrm{ID}_{2006}\right)$ and Januray $2012\left(\mathrm{ID}_{2012}\right)$ with respect to $\log _{10}$ (abundance) observed in January 2005; b) test for changes in the shape of AER after eruption $\left(\mathrm{ID}_{2012}\right)$ (model with interaction). $a=$ intercept, $S E=S t a n d a r d$ error, $R^{2}=$ Deviance explained by GAM, N=number of observations (=sampling plots $\times 3$ years), edf=estimated degrees of freedom. Asterisks indicate levels of significance: ${ }^{* * *} P<0.0001$, ${ }^{* *} P<0.001,{ }^{*} P<0.01,+P<0.05, P<0.1$.

Tabla 1. Modelos MAGs ajustados a los datos de AER para a) evaluar las diferencias en los niveles de $\log _{10}$ (abundancia) sobre tres gradientes altitudinales (Bayo, La Mona y Challhuaco) (modelo sin interacción). Los coeficientes paramétricos representan diferencias en unidades de $\log _{10}$ (abundancia) observadas en enero 2006 $\left(\mathrm{ID}_{2006}\right)$ y enero $2012\left(\mathrm{ID}_{2012}\right)$ respecto de $\log _{10}$ (abundancia) observada en enero 2005; b) evaluar la forma de AER luego de la erupción ( $\left.\mathrm{ID}_{2012}\right)$ (modelo con interacción). $\mathrm{a}=$ ordenada al origen, $\mathrm{SE}=$ error estándar, $\mathrm{R}^{2}=$ devianza explicada por MAG, $\mathrm{N}=$ número de observaciones (=sitios de muestreos $x 3$ años), edf=grados de libertad estimados. Los asteriscos indican los niveles de significancia: ${ }^{* * *} P<0.0001,{ }^{* *} P<0.001,{ }^{*} P<0.01,{ }^{+} P<0.05, \cdot P<0.1$.

\begin{tabular}{|c|c|c|c|c|}
\hline \multirow[t]{2}{*}{ a) } & \multicolumn{2}{|c|}{$\begin{array}{l}\text { Estimation of } \\
\text { parametric } \\
\text { coefficients }\end{array}$} & \multirow{2}{*}{$\begin{array}{c}\begin{array}{c}\text { Approximate } \\
\text { significance } \\
\text { of the smooth } \\
\text { term }\end{array} \\
\mathrm{F} \\
\text { (edf) }\end{array}$} & \multirow[t]{2}{*}{$\begin{array}{l}\mathrm{R}^{2} \\
(\mathrm{~N})\end{array}$} \\
\hline & $\begin{array}{cc}\mathrm{a} & \mathrm{ID}_{2006} \\
(\mathrm{SE}) & (\mathrm{SE})\end{array}$ & $\begin{array}{l}\mathrm{ID}_{2012} \\
(\mathrm{SE})\end{array}$ & & \\
\hline Bayo & $\begin{array}{cc}2.06^{* * *} & -0.76^{* *} \\
(0.08) & (0.12)\end{array}$ & $\begin{array}{l}-0.12 \\
(0.12)\end{array}$ & $\begin{array}{l}15.24^{* * *} \\
(5.17)\end{array}$ & $\begin{array}{c}88.3 \% \\
(27)\end{array}$ \\
\hline La Mona & $\begin{array}{cc}2.18^{* * *} & 0.07 \\
(0.07) & (0.09)\end{array}$ & $\begin{array}{c}0.10 \\
(0.09)\end{array}$ & $\begin{array}{l}11.81^{* * *} \\
(7.24)\end{array}$ & $\begin{array}{l}82 \% \\
(33)\end{array}$ \\
\hline Challhuaco & $\begin{array}{cc}1.56^{* * *} & 0.10 \\
(0.06) & (0.09)\end{array}$ & $\begin{array}{l}0.16^{\circ} \\
(0.09)\end{array}$ & $\begin{array}{l}11.72 * * * \\
(7.35)\end{array}$ & $\begin{array}{c}80.4 \% \\
(36)\end{array}$ \\
\hline b) & $\begin{array}{c}\text { Parametric } \\
\text { terms } \\
\text { Factor(year) } \\
\mathrm{F}_{\mathrm{df}=2}\end{array}$ & $\begin{array}{l}\text { Approximate } \\
\text { significance } \\
\text { of } \\
\text { smooth term } \\
\text { F } \\
\text { (edf) }\end{array}$ & $\begin{array}{c}\text { Approxi } \\
\text { Significar } \\
\text { smooth } \\
\text { for ID2 } \\
\text { F } \\
\text { (edf) }\end{array}$ & $\begin{array}{l}\text { imate } \\
\text { nce of } \\
\text { term } \\
2012 \\
\end{array}$ \\
\hline Bayo & $69.94^{* * *}$ & $\begin{array}{c}26.60^{* * *} \\
(6.52)\end{array}$ & $\begin{array}{r}5.4^{*} \\
(7.88\end{array}$ & \\
\hline La Mona & 0.77 & $\begin{array}{c}14.78^{* * *} \\
(7.48)\end{array}$ & $\begin{array}{l}2.83^{\circ} \\
(1.5)\end{array}$ & \\
\hline Challhuaco & 1.56 & $\begin{array}{c}12.52^{* * *} \\
(7.40)\end{array}$ & $\begin{array}{l}1.25 \\
(1.5)\end{array}$ & \\
\hline
\end{tabular}

Environmental factors associated with beetles' abundance at pre-and post-eruptive conditions

In January 2012, there was a significant decrease in above ground plant cover and plant species richness on our sampling plots, mainly in HERBSP, HERBCOV, SHRUBCOV and LITTER (Table 2). We often found that 
a)

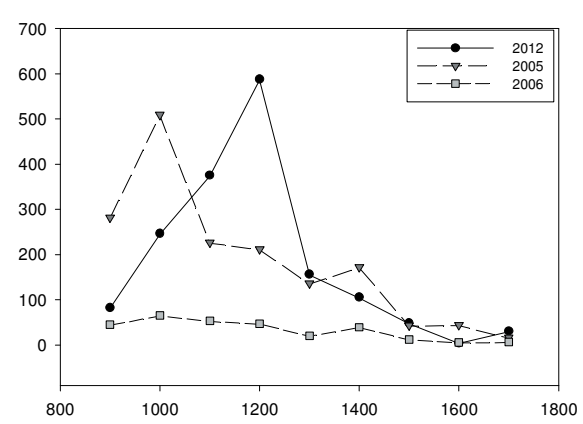

c)

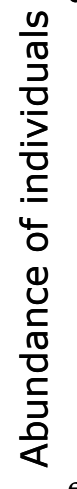

e)

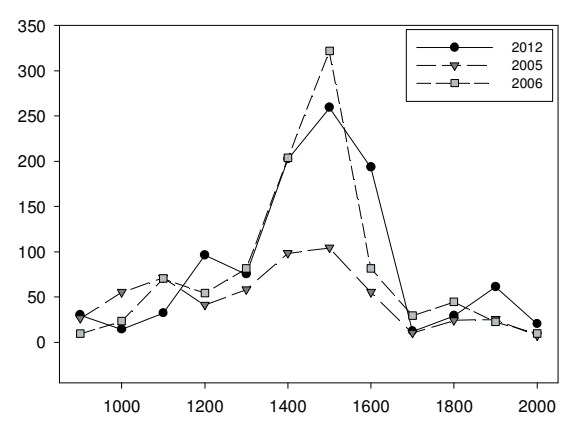

b)

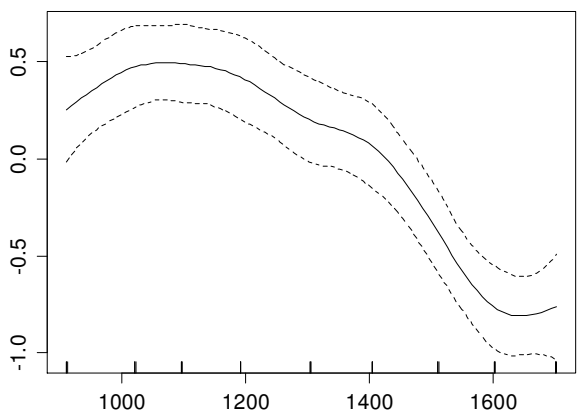

d)

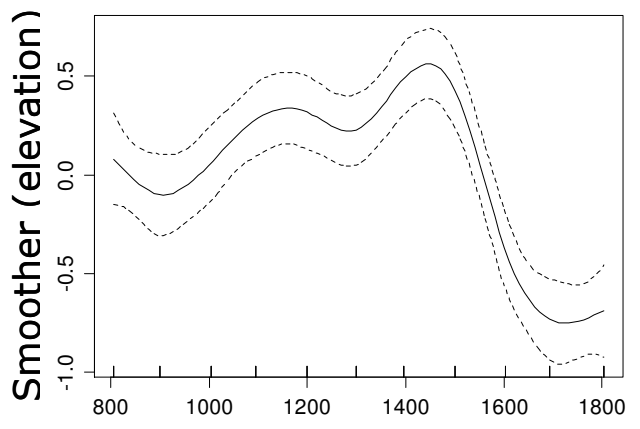

f)

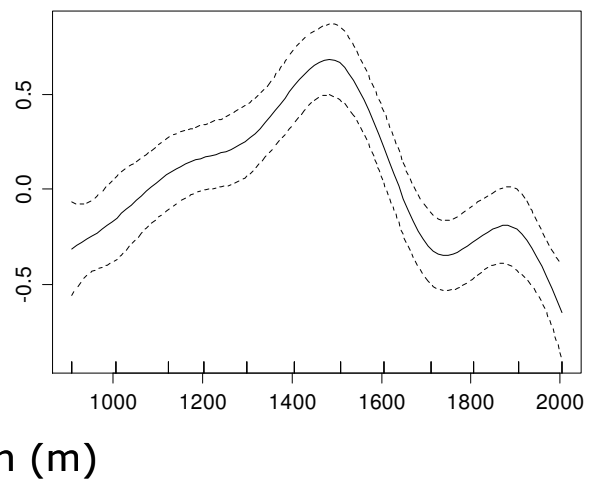

Figure 3. Elevational variation in abundance of individuals of epigaeic mountain beetles across years (left) and the overall trend (smoother fit) from all years (right), for Bayo (a-b), La Mona (c-d) and Challhuaco (e-f).

Figura 3. Variación altitudinal en la abundancia de individuos de coleópteros montanos epigeos entre años (izquierda) y tendencia promedio (ajuste suavizado) de todos los años (derecha), para Bayo (a-b), La Mona (c-d) y Challhuaco (e-f).

shrubs that were formerly in the understory were buried under the ash, thus changing the general appearance of our sampling plots (Figure 4). TMIN and TREECOV increased significantly. Post-eruptive samples of soils showed a lower content of OM, lower proportion of CLAY and SAND, lower BULDEN and higher $\mathrm{PHH} 2 \mathrm{O}$ and a higher proportion of SILT (Table 2).

Pre-eruptive variation in abundance was mainly associated with the proportion of GRAVEL in the soil and TREECOV, followed by TMIN; SHRUBSP and HUM were less important (Figure 5a, Appendix in Suplementary Information). In the summer immediately after the eruption, TREECOV (but not GRAVEL) continued to be an important factor to account for the abundance variation of epigaeic beetles followed by TVAR; TREESP and BULDEN were less important, and so was $\mathrm{ASH}$, which appeared last in the ranking of importance (Figure 5b, Appendix). 


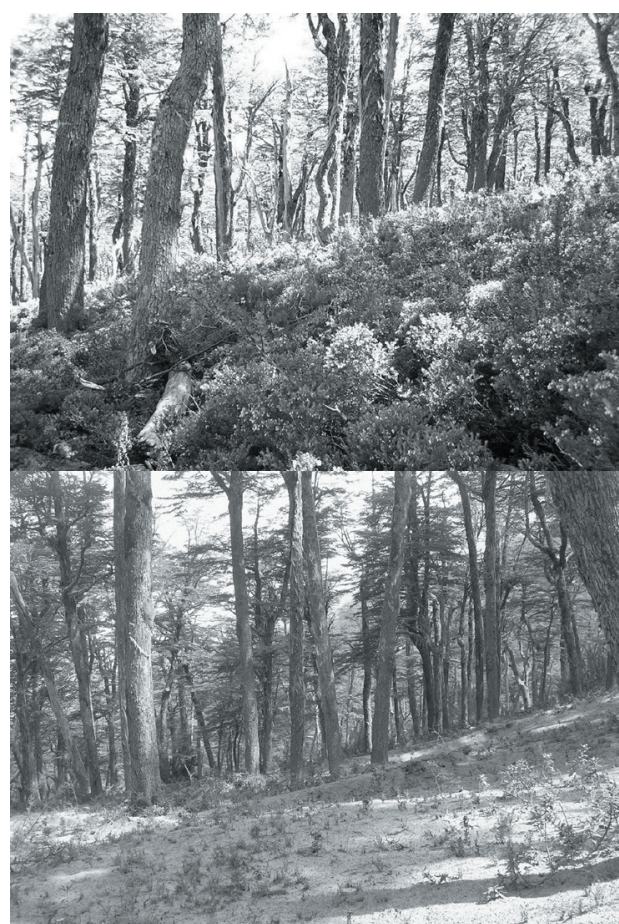

Figure 4. Environmental changes observed after the Puyehue-Cordón Caulle eruption. The pictures were taken at one of the sampling plots (Bayo, $1300 \mathrm{~m}$ ) from about the same standing position to be able to show differences between the environmental conditions before the eruption in 2005 (top) and after the eruption (down). Note that the shrubs in the understory shown in the top figure are buried under the ash in the bottom figure.

Figura 4. Cambios ambientales observados luego de la erupción del complejo volcánico Puyehue-Cordón Caulle. Las fotos fueron tomadas en uno de los sitios de muestreo (Bayo, $1300 \mathrm{~m}$ ) desde aproximadamente la misma posición para poder mostrar las diferencias en las condiciones ambientales entre antes de la erupción en 2005 (arriba) y después de la erupción (abajo). Nótese que los arbustos del sotobosque en la foto superior están enterrados debajo de la ceniza en la foto inferior.

\section{DisCUSION}

We confirmed that epigaeic mountain beetles are one important component of the biological legacy after the eruption of the PuyehueCordón Caulle volcanic complex. The high number of beetles captured during the first summer immediately after the eruption suggests that a great number of species were able to survive within our study area, thus maintaining (in La Mona) or rather increasing (in Bayo and Challuaco) the number of individuals caught after the eruption. This suggests that, at least in La Mona, Bayo and Challhuaco, total abundance of epigaeic beetles seems not to have been seriously affected by ash deposition; however, the shape of the AER did suggest a differential
Table 2. Overall environmental changes observed on the three mountains studied. Mean and standard deviation of environmental variables before (January 2005, 2006) and after (January 2012) Puyehue-Cordón Caulle volcanic eruption. $\mathrm{t}=\mathrm{t}$-test for paired samples, $\mathrm{df}=$ degrees of freedom, $P$ value=probability of error. TMIN=minimum daily temperature, $T V A R=$ daily temperature range, $\mathrm{SUN}=$ sun exposure, HERBSP=herb species richness, SHRUBSP=shrub species richness, TREESP=tree species richness, HERBCOV=proportion of herb cover, SHRUBCOV=proportion of shrub cover, TREECOV=tree canopy cover, LITTER=dry litter biomass, CLAY=proportion of clay, SILT=proportion of silt, SAND=proportion of sand, BULDEN=bulk density, GRAVEL=proportion of gravel, $\mathrm{PHH} 2 \mathrm{O}=$ water $\mathrm{pH}, \mathrm{PHVOLC}=$ volcanic $\mathrm{pH}, \mathrm{OM}=$ proportion of organic matter, HUM=soil humidity. See main text for details of variable measurements.

Tabla 2. Cambios ambientales observados en las tres montañas estudiadas. Media y desviación estándar de variables ambientes antes (enero 2005, 2006) y después (enero2012)delaerupcióndelcomplejovolcánicoPuyehueCordón Caulle. $\mathrm{t}=$ prueba de $\mathrm{t}$ para muestras apareadas, $\mathrm{df}=$ grados de libertad, valor de $P=$ probabilidad de error. TMIN=temperatura mínima diaria, TVAR=rango diario de temperatura, SUN=exposición solar, HERBSP=riqueza de especies de hierbas, SHRUBSP=riqueza de especies de arbustos, TREESP=riqueza de especies de árboles, HERBCOV=proporción de cobertura de hierbas, SHRUBCOV=proporción de cobertura de arbustos, TREECOV=cobertura del dosel arbóreo, LITTER=biomasa seca de hojarasca, CLAY=proporción de arcilla, SILT=proporción de limo, SAND=proporción de arena, BULDEN=densidad aparente, GRAVEL=proporción de gravas, $\mathrm{PHH} 2 \mathrm{O}=\mathrm{pH}$ agua, $\mathrm{PHVOLC}=\mathrm{pH}$ volcánico, $\mathrm{OM}=$ proporción de materia orgánica, $\mathrm{HUM}=$ humedad del suelo. Ver el texto principal para los detalles de las mediciones de las variables.

\begin{tabular}{|c|c|c|c|c|c|c|}
\hline \multirow[b]{2}{*}{ Variables } & \multicolumn{2}{|c|}{$\begin{array}{c}\text { Pre- } \\
\text { eruption }\end{array}$} & \multicolumn{2}{|c|}{$\begin{array}{c}\text { Post- } \\
\text { eruption }\end{array}$} & \multirow[b]{2}{*}{$\begin{array}{c}\mathrm{t} \\
(\mathrm{df}=31)\end{array}$} & \multirow[b]{2}{*}{$P$ value } \\
\hline & Mean & $\mathrm{Sd}$ & Mean & $S d$ & & \\
\hline IIN & 5.00 & 2.02 & 9.87 & 2.11 & -21.2169 & $<2.2 \mathrm{e}-16$ \\
\hline & 15.61 & 6.30 & 16.50 & 6.53 & -1.5361 & \\
\hline $\mathrm{N}$ & 3.31 & 1.53 & 3.38 & 1.64 & -1.00 & $0 . J 2$ \\
\hline ERB & 10.28 & 5.89 & 7.56 & 6.04 & 4.5227 & 8.39 \\
\hline III & 4.19 & 2.39 & 4.50 & 2.81 & -1.8986 & 0.06696 \\
\hline זיכל & 94 & 0.76 & 0.91 & 0.69 & 1 & \\
\hline ER & 26.09 & 27.49 & 3.05 & 5.19 & 5.4486 & 5.93 \\
\hline HRI & 28.72 & 32.41 & 18.47 & 21.13 & 2.4 & \\
\hline REF & 43.59 & 36.61 & 52.23 & 41.17 & -3.0732 & 0.0 \\
\hline & 134.82 & 161.15 & 8.78 & 13.11 & 4.7149 & 4.86 \\
\hline ter & 9.20 & 4.82 & 3.53 & 3.87 & 11.4014 & $1.28 \mathrm{E}-12$ \\
\hline 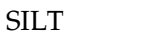 & 14.77 & 5.97 & 24.68 & 9.25 & -8.114 & 3.66 \\
\hline - & 76.04 & 9.32 & 71.80 & 10.10 & 2.9569 & 0.005 \\
\hline BULDE & 0.84 & 0.33 & 0.63 & 0.16 & 4.8542 & $3.26 \mathrm{E}-05$ \\
\hline GRAVEL & 11.35 & 9.72 & 13.38 & 11.84 & -1.1651 & 0.2529 \\
\hline PHH2O & 5.58 & 0.43 & 5.81 & 0.23 & -2.5565 & 0.01569 \\
\hline PHVOLC & 1.91 & 0.82 & 1.88 & 0.98 & 0.1829 & 0.8561 \\
\hline $\mathrm{OM}$ & 7.30 & 5.51 & 4.71 & 5.29 & 4.227 & 0.0001937 \\
\hline HUM & 20.60 & 9.24 & 22.43 & 9.96 & -1.0678 & 0.2939 \\
\hline
\end{tabular}

$\mathrm{S} \mathrm{d}=$ Standard deviation 
a)

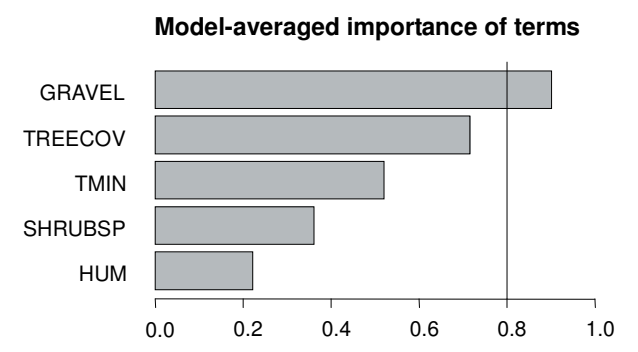

b)

\section{Model-averaged importance of terms}

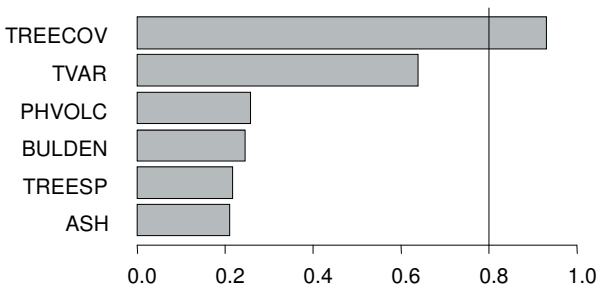

Figure 5. Ranking of importance of environmental factors that best accounted for the spatial variation in abundance at (a) pre- and (b) post- eruptive conditions, after the application of model averaging procedure (see main text for explanation)

Figura 5. Orden de importancia de los factores ambientales que mejor explicaron la variación espacial en la abundancia en condiciones (a) pre- y (b) post- eruptivas, luego de la aplicación del promediado de modelos (ver texto principal para una explicación).

ecological response along the gradient of ash deposition. The shape of the AER changed significantly after the eruption in Bayo where ash deposition was higher; in La Mona, ash deposition was comparatively lower and there was a weak tendency for the shape of AER to change. In Challhuaco, there were the lowest levels of ash deposition and no alteration of AER shape after the eruption. These findings support the idea that the presence of a continuum of disturbance intensities (i.e., here, in the level of ash deposition) may lead to associated patterns in biological legacies (Franklin 1990).

The abundance levels we observed shortly after the eruption could be associated with the seasonal timing of the eruption, which is often important to account for different post-eruptive landscapes (Foster et al. 1998). The eruption of the Puyehue - Cordón Caulle volcanic complex on June $4^{\text {th }}$, occurred in late autumn, a few weeks before the beginning of the austral winter; it is possible that many beetle species were already in a dormant stage (i.e., pupae) tucked away in soil, or within the tissues of plants and so were not exposed at the time of eruption. In temperate climates, the pupa is often the best equipped insect stage to carry the individual beetle through the winter, until day length, temperatures and moisture in spring and summer become appropriate for adult beetles to emerge (Evans \& Bellamy 2000; Topp 1994).

After the eruption of Mt. Saint Helens in May 1980, the selective death of organisms in the areas subjected only to tephra deposition left the structure and function of the affected ecosystems relatively intact (Foster et al. 1998). This was explained by the fact that by the time of the eruption, the mountain was covered with snow, and the presence of snow packs might had cushioned the blow, resulting in that a few months later, in late summer, almost the entire ecosystems showed evidence of resilience (del Moral 1981). Although we could not confirm the presence and extent of snow on our sampling plots by the time of eruption, we think that small shrubs that remained alive under the ash (e.g., Gaultheria spp.) were also part of the biological legacy that might have also favored the survival of beetles. We speculate that they possible might have acted as refuges for some insect species after they emerged from dormant stages, providing food for herbivores and suitable micro-habitats within the intricate structure of their branches.

The tendency for ash deposition to increase soil humidity could be another factor favoring beetle survival; in general, the higher the layer of ash deposited, the higher the water content we estimated at each sampling plot, $(b=0.79$, $\left.P<0.0001, R^{2}=0.64\right)$. This may be associated with a short term mulching action associated with ash that could increase soil water retention through lowering soil temperatures and decreasing direct evaporation from soil (Black \& Mack 1986). Probably because of the high ambient humidity typical of winter conditions at these temperate latitudes the ash deposited became quickly saturated and this may have protected insects from dehydration. This may explain why although laboratory assays suggested that Puyehue-Cordón Caulle volcanic ash could act as insecticide killing insects by dehydration (Buteler et al. 2011), we did not find evidence to suggest this effect on native beetles in their natural habitats. However, in the long term, ash deposition could result in other effects (e.g., increased runoff: Black \& Mack 1986), and 
hence long-term research is indispensable to fully understand the consequences of ash deposition on water dynamics that may potentially affect beetle abundances.

We confirmed that the association of the abundance of epigaeic beetles with environmental factors changed in the summer immediately after the eruption, although tree canopy cover continued to be an important variable. In general, the abundance of beetles increased as the tree canopy cover increased. However, the increase in tree canopy cover measured after the eruption should not be necessarily interpreted as an increase in primary production; in January 2012, our densitometer measurements could have been affected by the ash accumulation that pressed the tree branches out of their natural shape thus increasing shadow. The strong positive association of beetle abundance with canopy cover before and after the eruption can reflect the greater diversity and abundance of epigaeic beetles within the forests (as compared to the steppes) but it may also be associated with local effects within the forests, given that canopy cover can influence directly the availability of microhabitats at the ground level (e.g., Coleoptera: Niemelä et al. 1996).

Before the eruption, the abundance of beetles decreased with the increase in gravel percentage, and this factor appeared as the most important to account for their abundance. However, although we recorded no significant changes in the percentage of gravel after the eruption, we observed that gravel percentage was not important for AER in the summer immediately after the eruption (Table 2). Given that many coleopteran immature stages live underground, it would be interesting to follow more in depth, the course and possible alterations of this association to fully understand whether it may show a long term impact on beetle abundance.

Temperature at ground level was of relatively high importance to account for abundance patterns. The fact that minimum daily temperature was important at pre-eruptive times whereas daily temperature range was more important to account for post-eruptive patterns should not be overemphasized given that pre-eruptive temperature data was obtained from longer time series (i.e., dataloggers were established in the field for more than 150 days) than in the post-eruptive sampling period (one week). The remaining variables representing soil attributes and ash deposition were less important. Long term studies are needed to determine the extent to which abundance-environment associations observed in the summer immediately after the eruption are sustained.

The short-term effect of ash deposition on insect populations could have been selective within our study region, leading to differences in mortality among taxa. For instance, ash deposition did seriously affect the abundance of the invasive yellow jackets (Vespula spp), as no wasps were caught where ash deposition levels exceeded $3 \mathrm{~cm}$ (Masciochi et al. 2013). Short-term response to ash deposition has been also observed in honeybees (Apis mellifera), through experiments that demonstrated that workers were unable to see the flowers covered by ash, with this meaning extra allocation of energy during nectar foraging (Martínez et al. 2013). Laboratory trials also showed the toxicity of volcanic ash from Puyehue - Cordón Caulle eruption on the native grasshopper Dichroplus vittigerum (Fernández-Arhex et al. 2013). It has been suggested that for non-native species that have evolved in regions with little or no exposition to volcanic activity the effects could be dramatic (Masciochi et al. 2013).

In summary, the AER patterns found for epigaiec mountain beetles in the first summer after the volcanic eruption conforms to the idea that short-term effects of ash deposition may be subtle and that ground dwelling beetle assemblages remain as a significant part of the biological legacy that probably will contribute to ecosystem development and recovery. However, ash deposition could differently affect different stages of development, and we do not know whether beetles that survived in the first summer after the eruption, were able to complete their life cycle or will be able to sustain their populations in the presence of ash. Therefore, a long-term monitoring programme is warranted. This should evaluate the quantitative and qualitative changes in species richness and taxonomic composition in the beetle assemblage that could be associated with long term effects of ash deposition, and modification of other components of the biotic (e.g., the potential effect of removing the exotic Vespula spp on the reassembly of native fauna) and abiotic environments that could be crucial aspects to understand the structural and functional recovery of these mountain ecosystems. 
AcKnowledgements: J. Corley and an anonymous reviewer provided useful comments to improve the manuscript. We thank S. Aisen, F. Brook, M. Guala, S. Luzuriaga and J. Peluso for field and lab assistance. This work was part of a project funded by the British Ecological Society (SEPG award $3687 / 4553$ ) and the National Geographic/Waitt Foundation Grant (NGS Grant \#W201-11). The Administration of National Parks (Argentina) gave us permission to collect beetles in the Nahuel Huapi National Park.

\section{REFERENCES}

BAARS, MA. 1979. Catches in pitfall traps in relation to mean densities of carabid beetles. Oecologia, 41(1):25-46.

Barros, V; V Cordón; J Forguera; C Moyano; R Méndez; ET AL. 1983 Cartas de precipitación de la zona oeste de las provincias de Río Negro y Neuquén. Primera contribución Facultad de Ciencias Agrarias, Cinco Saltos, Neuquén.

Black, RA \& RN Mack. 1986. Mount St. Helens Ash: Recreating its effects on the steppe environment and ecophysiology. Ecology, 67:1289-1302.

BlaKeMORE, LC; PL SEARLE \& BK Daly. 1987a. Soil pH (Part 2). Pp. 9-12 in: NZ Soil Bureau (ed.). Methods for Chemical Analysis of Soils Scientific Report Nr. 80. NZ Soil Bureau, Department of Scientific and Industrial Research, Lower Hunt, New Zealand.

BlaKemore, LC; PL Searle \& BK Daly. 1987b. Soluble Salts (Part 9). Pp. 77-82 in: NZ Soil Bureau (ed.). Methods for Chemical Analysis of Soils Scientific Report Nr. 80. NZ Soil Bureau, Department of Scientific and Industrial Research, Lower Hunt, New Zealand.

Burnham, KP \& DR Anderson. 2002. Model Selection and Multimodel Inference. A Practical Information-Theoretic Approach, Second edn. Springer-Verlag, New York, USA.

Buteler, M; T Stadler; GP López García;MS Lassa; D Trombotto Liaudat; et al. 2011. Propiedades insecticidas de la ceniza del complejo volcánico Puyehue-Cordón Caulle y su posible impacto ambiental. Rev. Soc. Entomol. Argent., 70:149-156.

Calcagno, V \& C de Mazancourt. 2010. glmulti: An R Package for Easy Automated Model Selection with (Generalized) Linear Models. Journal of Statistical Software, 34:1-29. See http://www.jstatsoft.org/v34/i12.

CHeLI, G \& JC CORLEy. 2010. Efficient sampling of grounddwelling arthropods using pitfall traps in arid steppes. Neotrop. Entomol., 39:912-917.

ClaPPERTON, C. 1993. Quaternary geology and geomorphology of South America. Elsevier.

Dale, VH; CM CRissafulli \& FJ Swanson. 2005. 25 years of ecological change at Mount St. Helens. Science, 308: 961-962.

ELLIS, JI \& DC SCHNEIDER. 1997. Evaluation of a gradient sampling desing for environmental impact assessment. Environ. Monit. Assess., 48:157-172.

Evans, AV \& ChL Bellamy. 2000. An inordinate fondness for beetles. University of California Press.

Ezcurra, C \& C Brion. 2005. Plantas del Nahuel Huapi: Catálogo de la Flora Vascular del Parque Nacional Nahuel Huapi, Argentina Universidad Nacional del Comahue. Red Latinoamericana de Botánica, San Carlos de Bariloche, Argentina.

FernándeZ-Arhex, V; M Buteler; ME Amadio; A EnRIQueZ; AL PietrantuONO; ET AL. 2013. The effects of volcanic ash from Puyehue-Cualle range eruption on the survival of
Dichroplus vittigerum (Orthoptera: Acrididae). Fl. Entom., 96:286- 288

Ferreyra, M, A Cingolani; C EZCUrra \& D Bran. 1998. High-Andean vegetation and environmental gradients in northwestern Patagonia, Argentina. J. Veg. Sci., 9:307-316.

Foster, DR; DH KNIGHT \& JF FRANKLIN. 1998. Landscape patterns and legacies resulting from large, infrequent forest disturbances. Ecosystems, 1:497-510.

FrankLin, JF. 1990. Biological Legacies: A critical management concept from Mount St. Helens. Transactions North American Trans. Wildl. \& Nat. Res. Conf., 55:216-219.

Franklin, JF; D Lindenmayer; JA MacMahon; A McKee; JJ Magnuson; et Al. 2000. Threads of Continuity. Conserva tion Biology in Practice, 1(1):9-16.

Gaitán, JJ; JA Ayesa; F Umaña; F Raffo \& DB Bran. 2011. Cartografía del área afectada por cenizas volcánicas en las provincias de Río Negro y Neuquén. Documentos INTA EEA Bariloche. http://inta.gob.ar/documentos/ cartografia-del-area-afectada-por-cenizas-volcanicasen-las-provincias-de-rio-negro-y-neuquen.

HulBert, SH. 1984. Pseudoreplication and the design of ecological field experiments. Ecol. Monogr., 54:187-211.

JobbáGy, EG; JM PARUeLo \& RJC LEÓN. 1995. Estimación del regimen de precipitación a partir de la distancia a la cordillera el noroeste de la Patagonia. Ecol. Austral, 5:47-53.

KITZBERGER, T. 2013. Impact of Extreme and Infrequent Events on Terrestrial Ecosystems and Biodiversity. Pp. 209-223 in: Levin, SA (ed.). Encyclopedia of Biodiversity, second edition, Volume 4, Waltham, MA: Academic Press.

KLUTE, A. 1986. Methods of Soil Analysis. Part 1. Physical and Mineralogical Methods. American Society of AgronomySoil Science Society of America.

MartíneZ, AS; M Masciocchi; JM Villacide; G Huerta; L DANERI; ET AL. 2013. Ashes in the air: the effects of volcanic ash emissions on plant-pollinator relationships and possible consequences for apiculture. Apidologie, 44: 268-277.

MarsKe, KA; MA Ivie \& GM Hilton. 2007. Effects of volcanic ash on the forest canopy insects of Montserrat, west Indies. Environ. Entomol., 36:817-825.

Masciocchi, M; AJ Pereira; MV Lantschner \& JC Corley. 2013. Of volcanoes and insects: the impact of the Puyehue - Cordón Caulle ash fall on populations of invasive social wasps, Vespula spp. Ecol. Res., 28:199-205.

Del Moral, R. 1981. Life returns to Mount St. Helens. Nat. Hist., 90:36-49.

Niemelä, J; Y Haila \& P Punttila. 1996. The importance of small-scale heterogeneity in boreal forests: Variation in diversity in forest-floorinvertebrates across the succession gradient. Ecography, 19:352-368.

Paruelo, JM; A Beltrán; E Jobbágy; OE Sala \& RA Golluscio. 1998. The climate of Patagonia: general patterns and controls on biotic processes. Ecol. Austral, 8:85-101.

R Development Core Team. 2011. R: A language and environment for statistical computing. R Foundation for Statistical Computing, Vienna, Austria. ISBN 3-90005107-0, URL http:/ / www.R-project.org/.

Rudloff, W. 1981. World-Climates with tables of climatic data and practical suggestions. Wissenschaftliche Verlagsgesellschaft mbH Stuttgart.

SimkIN, T. 1993. Terrestrial volcanism in space and time. 
Annu. Rev. Earth Planet. Sci., 21:427-452.

TAlbot, SS; S LoOman-Talbot \& LR Walker. 2010. Posteruption legacy effects and their implications for longterm recovery of the vegetation on Kasatochi island, Alaska. Arct. Antarct. Alp. Res., 42:285-296.

Thomas, GW. 1996. Soil pH and Soil Acidity. Pp. 475-490 In: Bigham, JM (ed.). Methods of Soil Analysis. Part 3. Chemical Methods. SSSA Book Series Nr. 5. Soil Science Society of America, Madison, Wisconsin, USA.

Topp, W. 1994. Seasonal time partitioning and polymorphism in the developmental cycles of sympatric Staphylinoidea (Coleoptera) living in an unstable environment. Pp 277-312 in: Danks, HV (ed.). Insect life-cycle polymorphism: theory, evolution, and ecological consequences for seasonality and diapause control. Kluwer Academic Publishers.

Turner M; V Dale \& EH Everham. 1997. Fires, hurricanes, and volcanoes: Comparing large disturbances. Bioscience, 47:758-768.

UNDERWOOD, AJ. 1992. Beyond BACI: the detection of environmental impacts on populations in the real, but variable, world. J. Exp. Mar. Biol. Ecol., 161:145-178.

Villarosa, G, V Outes; A Hajduk; E Crivelli Montero; D SelLES; ET AL. 2006. Explosive volcanism during the Holocene in the Upper Limay River Basin: the effects of ashfalls on human societies, Northern Patagonia, Argentina. Quatern. Int., 158:44-57.

Werenkraut, V. 2010. Patrones altitudinales en la diversidad de coleópteros y hormigas epígeos del noroeste de la Patagonia argentina. Facultad de Ciencias Exactas y Naturales. Universidad de Buenos Aires. http: //digital.bl.fcen.uba.ar/gsdl-282/cgi-bin/library.cgi?a $=\mathrm{d} \& \mathrm{c}=$ tesis $\& \mathrm{~d}=$ Tesis_4785_Werenkraut.

Werenkraut, V \& A Ruggiero. 2014. The richness and abundance of epigaeic mountain beetles in northwestern Patagonia, Argentina: assessment of patterns and environmental correlates. J. Biogeogr., doi:10.1111/ jbi.12210

ZuUr, AF; EN IENo; NJ Walker; AA SAVELIEV \& GM Smith. 2009. Mixed effects models and extensions in ecology with $R$. Statistics for Biology and Health Series. Springer Science. 


\section{SUPPLEMENTARY INFORMATION}

Appendix. Model-averaged estimates of each variable coefficient, their unconditional variance, the total number of models each variable participated and its importance. Data from the three mountains were pooled for this analysis. To account for pre-eruptive variation in abundance we averaged the abundance from January 2005 and 2006. $\mathrm{SUN}=$ sun exposure, TVAR=daily temperature range, TMIN=minimum daily temperature, HERBSP=herb species richness, TREESP=tree species richness, SHRUBSP=shrub species richness, SHRUBCOV=proportion of shrub cover, HERBCOV=proportion of herb cover, LITTER=dry litter biomass, TREECOV=tree canopy cover, BULDEN=bulk density, CLAY=proportion of clay, SAND=proportion of sand, SILT=proportion of silt, GRAVEL=proportion of gravel, $\mathrm{PHVOLC}=$ volcanic $\mathrm{pH}, \mathrm{OM}=$ proportion of organic matter, $\mathrm{PHH} 2 \mathrm{O}=$ water $\mathrm{pH}, \mathrm{HUM}=$ soil humidity. Details of variable measurements are given in main text.

Apéndice. Estimaciones de los coeficientes de cada variable a partir de los modelos promedio, su varianza incondicional, el número total de modelos en los que cada variable participó y su importancia. Los datos de las tres montañas fueron agrupados para este análisis. Para explicar la variación de la abundancia pre-eruptiva promediamos la abundancia de enero 2005 y 2006. SUN=exposición solar, TVAR=rango diario de temperatura, TMIN=temperatura mínima diaria, HERBSP=riqueza de especies de hierbas, TREESP=riqueza de especies de árboles, SHRUBSP=riqueza de especies de arbustos, SHRUBCOV=proporción de cobertura de arbustos, HERBCOV=proporción de cobertura de hierbas, LITTER=biomasa seca de hojarasca, TREECOV=cobertura del dosel arbóreo, BULDEN=densidad aparente, CLAY=proporción de arcilla, $\mathrm{SAND}=$ proporción de arena, $\mathrm{SILT}=$ proporción de limo, GRAVEL=proporción de gravas, $\mathrm{PHVOLC}=\mathrm{pH}$ volcánico, $\mathrm{OM}=$ proporción de materia orgánica, $\mathrm{PHH} 2 \mathrm{O}=\mathrm{pH}$ agua, $\mathrm{HUM}=$ humedad del suelo. Detalles de las mediciones de las variables se dan en el texto principal.

\begin{tabular}{|c|c|c|c|c|c|c|c|c|}
\hline & \multicolumn{4}{|c|}{ Pre- eruptive (January 2005 - January 2006) } & \multicolumn{4}{|c|}{ Post- eruptive (January 2012) } \\
\hline Variables & Coefficient & $\begin{array}{c}\text { Unconditional } \\
\text { variance }\end{array}$ & $\begin{array}{c}\text { Number } \\
\text { of } \\
\text { models }\end{array}$ & $\begin{array}{l}\text { Importance } \\
\text { (wi) }\end{array}$ & Coefficient & $\begin{array}{l}\text { Unconditional } \\
\text { variance }\end{array}$ & $\begin{array}{c}\text { Number of } \\
\text { models }\end{array}$ & $\begin{array}{l}\text { Importance } \\
\text { (wi) }\end{array}$ \\
\hline \multicolumn{9}{|c|}{ Ambient energy } \\
\hline SUN & $-1.994 \mathrm{e}-03$ & 0.001 & 4 & 0.214 & $3.971 \mathrm{e}-03$ & 0.001 & 4 & 0.207 \\
\hline TVAR & $-2.432 \mathrm{e}-01$ & 0.056 & 4 & 0.646 & $-5.10 e-01$ & 0.032 & 4 & 0.973 \\
\hline TMIN & $5.617 \mathrm{e}-01$ & 0.050 & 4 & 0.947 & $3.042 \mathrm{e}-01$ & 0.036 & 4 & 0.831 \\
\hline \multicolumn{9}{|c|}{ Plant species richness } \\
\hline HERBSP & $-9.247 e-02$ & 0.019 & 4 & 0.428 & $-9.621 \mathrm{e}-02$ & 0.020 & 4 & 0.433 \\
\hline TREESP & $3.134 \mathrm{e}-01$ & 0.079 & 4 & 0.674 & $3.101 \mathrm{e}-01$ & 0.071 & 4 & 0.691 \\
\hline SHRUBSP & $3.119 \mathrm{e}-01$ & 0.071 & 4 & 0.696 & $2.118 \mathrm{e}-01$ & 0.061 & 4 & 0.550 \\
\hline \multicolumn{9}{|c|}{ Vegetation cover and litter } \\
\hline SHRUBCOV & $6.223 \mathrm{e}-03$ & 0.000 & 8 & 0.203 & $-8.649 e-03$ & 0.001 & 8 & 0.208 \\
\hline HERBCOV & $8.981 \mathrm{e}-02$ & 0.015 & 8 & $0-473$ & $-4.192 \mathrm{e}-02$ & 0.007 & 8 & 0.313 \\
\hline LITTER & $-1.986 \mathrm{e}-01$ & 0.030 & 8 & 0.706 & $-1.186 \mathrm{e}-01$ & 0.024 & 8 & 0.501 \\
\hline TREECOV & $8.962 \mathrm{e}-01$ & 0.017 & 8 & 0.999 & $7.941 \mathrm{e}-01$ & 0.021 & 8 & 0.999 \\
\hline \multicolumn{9}{|c|}{ Soil - Physical composition } \\
\hline BULDEN & $-8.170 \mathrm{e}-02$ & 0.020 & 16 & 0.325 & $-4.183 e-01$ & 0.079 & 16 & 0.797 \\
\hline CLAY & $-1.73 e-01$ & 0.47 & 16 & 0.462 & $1.030 \mathrm{e}+00$ & 8.275 & 16 & 0.639 \\
\hline SAND & $-1.264 \mathrm{e}-01$ & 1.528 & 16 & 0.469 & $3.427 \mathrm{e}+00$ & 56.270 & 16 & 0.422 \\
\hline SILT & $3.514 \mathrm{e}-01$ & 0.730 & 16 & 0.752 & $3.364 \mathrm{e}+00$ & 47.205 & 16 & 0.528 \\
\hline GRAVEL & $-4.496 e-01$ & 0.037 & 16 & 0.914 & $-6.593 e-02$ & 0.014 & 16 & 0.331 \\
\hline \multicolumn{9}{|c|}{ Soil - Chemical and organic properties } \\
\hline PHVOLC & $5.510 \mathrm{e}-03$ & 0.001 & 8 & 0.210 & $-3.998 \mathrm{e}-01$ & 0.080 & 8 & 0.774 \\
\hline $\mathrm{OM}$ & $4.883 \mathrm{e}-02$ & 0.01 & 8 & 0.289 & $1.320 \mathrm{e}-01$ & 0.036 & 8 & 0.458 \\
\hline $\mathrm{PHH} 2 \mathrm{O}$ & $-2.088 \mathrm{e}-01$ & 0.038 & 8 & 0.669 & $-1.014 \mathrm{e}-01$ & 0.024 & 8 & 0.413 \\
\hline HUM & $4.954 \mathrm{e}-01$ & 0.037 & 8 & 0.942 & $1.139 \mathrm{e}-01$ & 0.036 & 8 & 0.394 \\
\hline
\end{tabular}

